\title{
Kandungan Hexadecanoic Acid, Ethyl Ester pada Nigela Sativa untuk Prediksi Apoptosis pada Sel HeLa
}

\author{
Kusmayra Ambarwati ${ }^{1}$, Miftahul Jannah ${ }^{1}$, Asyifa Robiatul Adawiyah ${ }^{2}$ \\ 1) Fakultas Ilmu Kesehatan Prodi Sarjana Terapan Kebidanan \\ 2) Pasca Sarjana Ilmu Kesehatan Masyarakat Universitas Respati Indonesia \\ Email: kusyma
}

\begin{abstract}
ABSTRAK
Antioksidan dan herbal adalah zat yang dapat mencegah terjadinya kanker serviks. Angka kejadian kanker serviks di Indonesia masih tinggi. Setiap hari muncul 40-45 kasus baru, yang berarti 20-25 orang meninggal akibat kanker serviks di Indonesia. Penelitian terdahulu membuktikan terdapat tumbuhan, buah - buahan dan biji - bijian yang mengandung antioksidan tinggi dan dipercaya dapat mencegah dan mengurangi kesakitan akibat kanker serviks. Selain itu banyak herbal yang juga ditemukan di Indonesia yang diketahui memiliki efek pada sel kanker. Salah satunya yang dapat ditemukan di Indonesia adalah Jinten Hitam (Nigela Sativa). Saat ini masyarakat belum banyak yang memanfaatkan sumber daya alam yang tersedia yang diduga dapat mencegah kanker serviks ini. Studi ini merupakan penelitian awal untuk membahas mengenai kandungan Hexadecanoic Acid, Ethyl Ester pada Jinten Hitam untuk nantinya dapat digunakan sebagai prediksi apoptosis pada sel HeLa.
\end{abstract}

Kata Kunci : Buah Tin, Sel Hela, Hexadecanoic Acid

\begin{abstract}
Antioxidants and herbs are substances that can prevent cervical cancer. The incidence of cervical cancer in Indonesia is still high. Every day 40-45 new cases emerge, which means 2025 people die from cervical cancer in Indonesia. Previous research has shown that there are plants, fruits and seeds that contain high antioxidants and are believed to prevent and reduce pain due to cervical cancer. In addition, many herbs that are also found in Indonesia are known to have an effect on cancer cells. One of them that can be found in Indonesia is Black Cumin (Nigela Sativa). Currently, not many people use the available natural resources that are suspected of being able to prevent cervical cancer. This study is a preliminary study to discuss the content of Hexadecanoic Acid, Ethyl Esters in Black Cumin so that it can later be used as a prediction of apoptosis in HeLa cells.
\end{abstract}

Keywords: Tin Fruit, Hela Cells, Hexadecanoic Acid

\section{PENDAHULUAN}

Kejadian kanker serviks di Indonesia adalah $16 / 100.000$ perempuan ${ }^{1}$.Data penderita kanker serviks tahun 2016 adalah 17,8 juta jiwa dan pada tahun 2017 menjadi 21,7 juta jiwa, terjadi peningkatan
3,9 persen jumlah pengidap kanker. Hal ini membuat kanker serviks disebut sebagai penyakit pembunuh wanita nomor 1 di Indonesia². Selain itu juga membuat Indonesia menempati nomor dua dalam jumlah tertinggi penderita kanker serviks di

http://ejournal.urindo.ac.id/index.php/kesehatan

Article History : 
dunia $^{3}$. Hal ini cukup memprihatinkan karena sebagian besar kasus baru terdeteksi setelah stadium lanjut serta upaya kesehatan ${ }^{4.5}$. Hal yang sering dilakukan adalah pengobatan dan terapi lanjut yang keberhasilannya masih minim.

Pengobatan alternatif telah muncul sebagai cara yang menarik untuk mengobati atau menyembuhkan kanker, dan beberapa tanaman dan konstituen baru-baru ini disetujui dikembangkan karena aman, efektif, dan lebih murah untuk mengelola berbagai jenis kanker. Beberapa tanaman obat telah ditemukan mengandung senyawa aktif yang mampu mengganggu homeostasis sel kanker ${ }^{4,6}$.

Indonesia memiliki kekayaan alam berupa tanaman herbal yang sangat mudah didapatkan. Beberapa tanaman herbal yang dipercayai sebagai anti kanker antara lain adalah Jinten Hitam ${ }^{7}$, Brotowali (Tinospora Cordifolia). Buah -buah ini sangat mudah didapatkan di Indonesia, namun belum diketahui efek apoptosis nya bila diberikan bersamaan pada sel HeLa sebagai upaya pencegahan dan pengobatan kanker.

Studi yang dilakukan ini merupakan kajian awal untuk mengetahui salah satu kanduangan pada Jinten Hitam yang dicurigai memiliki efek apoptosis pada sel HeLa

\section{METODE PENELITIAN}

Rancangan

penelitian

ini

menggunakan metode observasi dan analisis pengujian bahan / Sample. Sample pada penelitian ini adalah ekstraks etanol 70 \% Jinten Hitam. Sample kemudian diuji dengan metode analisis senyawa Gas Cromatografy Mass Spectrometry (GCMS) dengan menguji adanya senyawa tertentu sesui dengan library alat uji.

Berikut ini adalah langkah dari uji tersebut:

1. Pengeringan Jinten Hitam

Pengeringan dilakukan dengan metode sederhana, yaitu pengovenan secara sederhana.

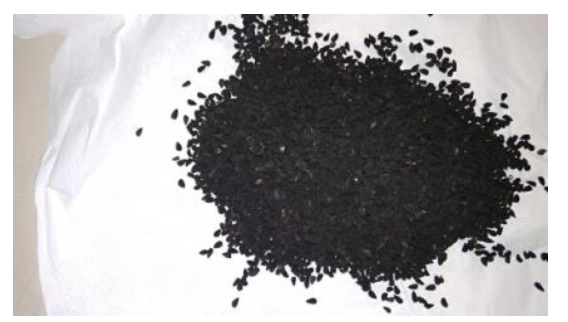

Gambar 1: Proses pengeringan

2. Penepungan

Proses penepungan juga dilakukan dengan metode sederhana, yaitu dengan menghaluskan buah Tin yang sudah kering dan melakukan pengayakan 30 mess.
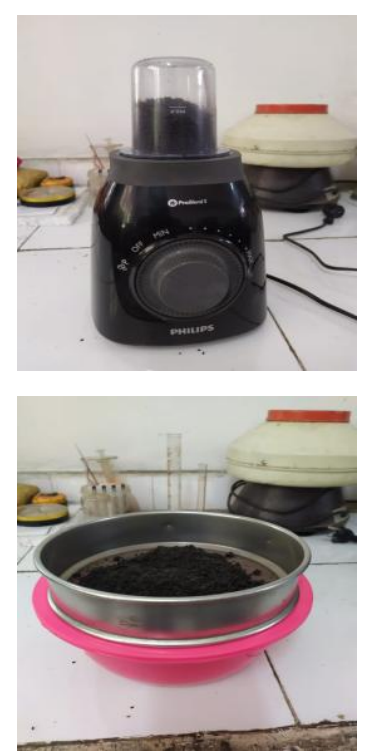
Gambar 2. Proses Penepungan

3. Ekstraksi

Ekstraksi dilakukan dengan etanol $70 \%$

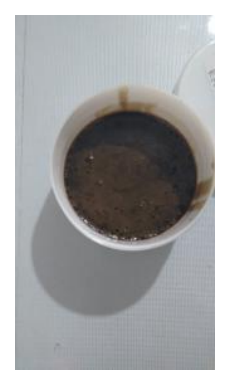

Gambar 3 : Ekstrak Jinten Hitam

4. Uji GCMS

ETIK

Penelitian ini telah memenuhi persyaratan etik dan telah disetujui untuk dilaksanakan penelitian dengan memperhatikan prinsip - prinsip yang dinyatakan oleh Komite Etik Penelitian Kesehatan Universitas Respati Indonesia.

\section{HASIL PENELITIAN}

Hasil penelitian menunjukkan bahwa terdapat senyawa HexadecanoicAcid, Ethyl Ester pada Buah Tin dengan analisis sebagai berikut:

\begin{tabular}{ccccc}
\hline Jenis Sample & RT & Quality & Senyawa & Kandungan \\
\hline Jinten Hitam & 28.169 & 98 & HexadecanoicAcid,Ethyl Ester & $16.22 \%$ \\
\hline
\end{tabular}

Rumus Kimia : $\mathrm{C} 18 \mathrm{H} 36 \mathrm{O} 2$

Struktur Kimia:

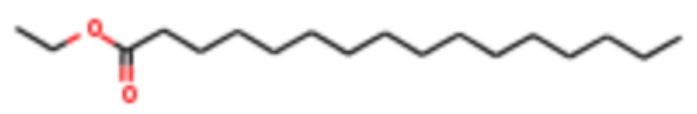

Gambar 4: Struktur HexadecanoicAcid,Ethyl Ester

PEMBAHASAN

Analisis hasil penelitian menunjukkan bahwa terdapat sekitar 16.22 $\% \quad$ kandungan HexadecanoicAcid,Ethyl Ester pada buah Jinten Hitam. Hasil analisis diketahui bahwa aktifitas HexadecanoicAcid,Ethyl Ester antara lain adalah Antioksidan, Hemolitik,Hipokolesterolemia, Rasa, Nematicide, Anti-androgenic dan anti kanker ${ }^{9}$. Sumber yang semakin memperkuat adalah bahwa zat aktif ini merupakan bagian dari senyawa Flavonoid yang aktif sebagai anti kanker ${ }^{10}$.

Adanya aktifitas anti kanker pada HexadecanoicAcid,Ethyl Ester ini akan memiliki kecenderungan bahwa zat aktif ini dapat menimbulkan efek apoptosis juga, terutama pada sel $\mathrm{HeLa}^{10}$. 


\section{Jurnal Bidang Ilmu Kesehatan}

Kesimpulan awal yang dapat diambil dalam studi ini adalah, adanya kandungan HexadecanoicAcid,Ethyl Ester pada ekstrak Jinten Hitam, diprediksi dapat memberikan efek apoptosis pada sel HeLa sebab aktivitas awal HexadecanoicAcid,Ethyl Ester ini diketahui memiliki aktivitas anti kanker.

\section{DAFTAR PUSTAKA}

Kemenkes RI. Data dan Informasi

Kesehatan. Jakarta. Kemenkes RI, 2015

YKI. Kanker serviks Pembunuh Nomor Satu Perempuan di Indonesia. Jakarta. Kumparan, 2017.

Vetriciawizach.Jumlah Kanker Serviks Indonesia Nomor -2 di Dunia. Indonesia. CNN.2017.

Yin, S.-Y., Wei, W.-C., Jian, F.-Y., and Yang, N.-S. therapeutic applications of herbal medicines for cancer patients. Evid. Based Complement. Altern. Med. 2013:302426. doi: $10.1155 / 2013 / 302426$

Salman, N. et al. Association of High Risk Human Papillomavirus and Breast cancer: A UK based Study. Sci. Rep.(2017) 7, 43591.
Siegel, R. L., Miller, K. D., and Jemal, A. Cancer statistics, 2016. CA Cancer J. 2016.Clin. 66, 7-30. doi: 10.3322/caac.21332

Polu et al. Assessment of free radical scavenging and anti-proliferative activities of Tinospora cordifolia Miers (Willd). BMC Complementary and Alternative Medicine . Inggris. 2017

Khodarahmi et al, Cytotoxic Effects of Different Extracts and Latex of Ficus carica L. on HeLa cell Line. Iranian Journal of Pharmaceutical Research (2011), 10 (2): 273-277.

NIH. Gama - Sitosterol . National Center for Advancing Translational Sciences (NCATS),2019

Yamato, Gayor. Thepeutic potential of inhibitory of the NF.KB pathway in the treatment of inflammation and cancer, Journal of clinical investigation. 2002, 493-503. 